\title{
The Screening Hypothesis and the Returns to Schooling in Argentina
}

\author{
Harry Anthony Patrinos ${ }^{1, *} \&$ Maria Paula Savanti ${ }^{2}$ \\ ${ }^{1}$ World Bank, Washington DC, 20433, U.S.A. \\ ${ }^{2}$ Kennedy School of Government, Harvard University, Cambridge MA, U.S.A. \\ *Corresponding author: Tel: 202-473-5510 E-mail: hpatrinos@worldbank.org
}

Received: February 20, 2014 Accepted: July 9, 2014 Published: August 26, 2014

doi:10.5296/rae.v6i3.5157～URL: http://dx.doi.org/10.5296/rae.v6i3.5157

\begin{abstract}
We conduct four tests of screening in education. We apply our methodology to labor market data from Argentina, using two points in time, a period during which the returns to schooling in Argentina increased. There do not appear to be significant increases associated with years of schooling that would represent the attainment of a primary or secondary certificate. The only signal that there might be screening occurs at 17 years of schooling which could be argued represents the attainment of a tertiary education degree. However, 15 years of schooling also represents a significant threshold in 2002. The returns to schooling are higher in the private sector. Much of the increase in the returns to schooling overall is due to the increase in the returns to tertiary education. The returns to complete university are higher in the private sector. This provides no evidence of screening since the private sector seeks to maximize profits and recognizes the higher productivity of the more educated. Overall, there is little evidence of screening driving the returns to schooling.
\end{abstract}

Keywords: Returns to schooling, Argentina, screening 


\section{Introduction}

According to screening theories, those with more schooling tend to earn more not solely because schooling makes them more productive, but because schooling acts as a credential. This view was early on dismissed due to a lack of evidence (Layard and Psacharopoulos 1974). More recent analyses, exploiting data that allow researchers to disaggregate earnings by years of completed schooling, has questioned the linearity of the earnings function approach, suggesting that there are significant discontinuities associated with diploma years, thus suggesting evidence of sheepskin effects in the returns to schooling and hence screening (Hungerford and Solon 1987; Jaeger and Page 1996; Gibson 2000; Bedard 2001; Bauer, Dross and Haisken-DeNew 2005; Brown and Sessions 2006; Pons 2006; Skalli 2007; Bitzan 2009). This returning theme in the literature, that is, the extent to which estimated returns to schooling reflects productivity differences, is something we turn to empirically using recent data from a country where it is documented that there is a strong relationship between demand for education and earnings over the last decade: Argentina. Central to human capital theory is that education directly augments individual productivity and, therefore, earnings (Becker 1964; Schultz 1961). The alternative to this explanation - that education serves to "sort" individual into higher productivity jobs, by "signaling” or "screening” more productive individuals (Spence 1973; Arrow 1973; Stiglitz 1975) - is what we test.

In this paper four tests are applied to ascertain the extent to which screening drives the observed returns to schooling. One test for screening looks at the returns for people with a complete education versus those who dropped out (Layard and Psacharopoulos 1974); hereafter referred to as the LP-test. If education is acting as a signal, then certification from a course should convey more information to prospective employees about an applicant's ability. Returns for completers, therefore would be higher than returns for non-completers.

We also estimate a variant of the LP-test in order to control for the fact that those with incomplete levels of schooling have attained various years of schooling. Therefore, we also control for both levels and years. That is, we estimate a spline function where we control for both years of schooling within each level of schooling (that is, primary, secondary and tertiary), and a dummy variable indicating completion of each level of schooling.

A third test, and variant of the above, accounts for the timing of the dropout decision by examining year-to-year returns and looking for discontinuities in the estimates at years corresponding to the termination of levels. The so-called "sheepskin effects" of education ask whether it is years of schooling or highest qualifications that are more important (Jaeger and Page 1996; Arabsheibani and Manfor 2001). We estimate a string of dummy variables, one for each year of schooling, and look for discontinuities associated with specific schooling levels (Hungerford and Solon 1987; Patrinos 1996). Others use splines to account for years associated with completion of degrees in the earnings equation, along with a continuous variable for years of schooling (Mora 2003; Pons and Blanco 2005).

Finally, we test what has come to be known as the "weak versus the strong version of the screening hypothesis." This hypothesis draws a distinction between employers paying irrational wages at the initial hiring point (weak) or continuously thereafter (strong) 
(Psacharopoulos 1979). It is also known as the P(Psacharopoulos)-test. The methodology consists of comparing the rate of return to education across "competitive" and "non-competitive" sectors. It is assumed that screening is more likely in the latter sector because wages are more bureaucratic and linked to education. Wages in the competitive sector, on the other hand, will be largely determined by traditional market forces. Most applications of the "weak versus the strong version of the screening hypothesis" have failed to find any evidence of strong, if any, screening (see, for example, Arabsheibani and Rees 1998; Brown and Sessions 1999; Cohn et al. 1987; Lambropoulos 1992; and for a recent review see Brown and Sessions 2004).

Our paper contributes to the literature by adding new estimates for a middle-income country drawn from a year at which one of the worst financial and economic crises ever hit the country. The economy went into a major decline, earnings fell drastically, and the labor market was severely affected. Yet, throughout this period the returns to schooling increased significantly. While our results point to some level of screening, at some levels of schooling, the overall findings are consistent with a human capital interpretation of the relationship between education and earnings.

\section{Returns to Schooling in Argentina}

The returns to schooling in Argentina are relatively high and increased over the last decade. The rate of return to a year of schooling increased from 8.6 to 11.4 percent from 1992 to 2002 (Savanti and Patrinos 2005), representing a 32 percent increase. The returns to primary schooling remained unchanged, as did the low returns to incomplete secondary. The returns to complete secondary increased but not nearly by as much as did the returns to university education. While complete university has a high rate of return, the rate of return for incomplete university increased quicker. In 1992 the highest private returns were for primary schooling; by 2002 the highest returns were for complete university.

The reasons for the increase in the returns to schooling have been studied elsewhere. Fiszbein et al. (2007) estimate the returns to schooling in urban Argentina for a 10-year period. In addition to comparable earnings functions, they also estimate the returns using quantile regression analysis to detect differences in the returns across the distribution. Over time, men in higher quantiles have higher returns to schooling compared with those in the lower quantiles. For women, returns are highest at the lowest quantile. The returns to education increased during the past decade and the authors do not rule out that increased demand for skills is driving the increasing returns over the decade (Fiszbein et al. 2007). Galiani and Sanguinetti (2003) test whether trade liberalization played any role in shaping the wage structure during the 1990s. By looking at sectors of the economy where import penetration deepened and observing whether wage inequality increased, they argue that despite some evidence of a trade role, it explains only a small proportion of the observed rise in inequality. 


\section{Data}

Data used in this paper come from the 2002 household surveys carried out by the National Institute of Statistics and Census (INDEC) twice a year since the 1970s. The survey, known as the Permanent Household Survey (Encuesta Permanente de Hogares or EPH), has incorporated new regions and cities over time in order to have better coverage of urban households. It now reaches approximately 70 percent of the urban population. Earnings functions are estimated for men and women jointly and separately. The samples include all workers 14-65 year of age with positive employment earnings.

\section{Results}

We apply four tests of screening: (1) Layard-Psacharopoulos (L-P) test on completers versus dropouts; (2) L-P test variant on levels versus years; (3) sheepskin effects (or non-linearities) by estimating a string of dummy variables for each schooling year of schooling and looking for discontinuities associated with levels; and (4) the "weak versus the strong version of the screening hypothesis" (P-test) by looking at returns in the public and private sectors of the economy.

\subsection{Layard-Psacharopoulos Test (L-P test)}

In the case of both secondary and university education, it would appear that there is a premium for completing the level (Table 1). We estimate returns to schooling comparing complete and incomplete university and secondary. In both cases, the returns are higher for completing the degree. The earnings gain is particularly large at the secondary level, suggesting that screening is important at this level. The earnings gain associated with complete university education is not, however, particularly large. Thus, if anything, there could be some level of screening for complete secondary education.

Table 1. Determinants of Earnings

\begin{tabular}{lcll}
\hline Variable & \multicolumn{2}{l}{ Coefficient } & Rate of return \\
\hline Primary complete & 0.218 & $(0.030)$ & 10.9 \\
Secondary incomplete & 0.386 & $(0.032)$ & 11.2 \\
Secondary complete & 0.674 & $(0.032)$ & 15.2 \\
Tertiary incomplete & 0.956 & $(0.037)$ & 11.3 \\
Tertiary complete & 1.368 & $(0.033)$ & 13.9 \\
Experience & 0.040 & $(0.002)$ & \\
Experience $^{2}$ & -0.001 & $(0.000)$ & \\
Constant & -0.422 & \\
$\mathrm{R}^{2}$ & 0.270 & \\
$\mathrm{~N}$ & 9,309 & \\
\hline
\end{tabular}

Source: EPH 2002

Note: Standard errors in parentheses; rates of return calculated as coefficient to a level minus previous level over years of schooling required for that level; in the case of primary 2 years of 
foregone earnings are assumed

\subsection{L-P test variant on levels versus years}

In order to control for the fact that those with incomplete levels of schooling have attained various years of schooling we control for levels and years (Table 2). The variables primary complete, secondary complete and tertiary complete are dummies that take the value 1 when that is the highest level of education achieved. The variables years of primary, secondary and tertiary are the year achieved but instead of being all in one variable it is split into three. In this test the premium associated with completing the degree is much less than before: 2.5 percent at the secondary level and a mere 1.6 percent at the tertiary level. The returns to secondary years of schooling are not very high at only 7.7 percent. But the returns to years of tertiary are large, at over 15 percent. Therefore, screening is much less important at the tertiary level, and not at all at the primary level.

Table 2. Earnings Functions

\begin{tabular}{|c|c|c|c|}
\hline & Coefficient & Certificate premium & Rate of return \\
\hline Primary complete & $\begin{array}{l}0.021 \\
(0.035)\end{array}$ & n.s. & \\
\hline Secondary complete & $\begin{array}{l}0.095 \\
(0.031)\end{array}$ & 2.5 & \\
\hline Tertiary complete & $\begin{array}{l}0.160 \\
(0.036)\end{array}$ & 1.6 & \\
\hline Years of primary & $\begin{array}{l}0.054 \\
(0.010)\end{array}$ & & 5.4 \\
\hline Years of secondary & $\begin{array}{l}0.077 \\
(0.010)\end{array}$ & & 7.7 \\
\hline Years of tertiary & $\begin{array}{l}0.153 \\
(0.011)\end{array}$ & & 15.3 \\
\hline Experience & $\begin{array}{l}0.040 \\
(0.002)\end{array}$ & & \\
\hline Experience $^{2}$ & $\begin{array}{l}-0.001 \\
(0.000)\end{array}$ & & \\
\hline Constant & -0.607 & & \\
\hline $\mathrm{R}^{2}$ & 0.282 & & \\
\hline $\mathrm{N}$ & 9,309 & & \\
\hline
\end{tabular}

Source: EPH 2002

Note: Standard errors in parentheses; certificate premium assumed to be coefficient minus previous level over number of years of schooling required for that level 


\subsection{Sheepskin Effects}

We estimate year-to-year returns to schooling in order to detect discontinuities at years corresponding to levels, or non-linearities, which could be taken as evidence of sheepskin effects. It is generally assumed in earnings function analyses that an extra year of schooling raises earnings - through productivity - by the same percentage point at all levels of schooling. Researchers have questioned this assertion and made various arguments that the returns to schooling are not linear. Among the early critics were the supporters of screening, or 'credentialism,' who claimed that the returns to schooling are higher at the completion of the different levels of schooling. In other words, workers are rewarded not for the productivity-enhancing contributions of schooling but rather for obtaining the certificate that comes with completing the level of schooling — the so-called "sheepskin" effects.

Recently Belman and Heywood (1991) and Hungerford and Solon (1987) confirmed the existence of sheepskin effects in the returns to education by finding significantly larger returns to diploma years than to other years of education. Non-linearities in the returns to education were thus interpreted as showing that in addition to any role education plays in making workers more productive, it provides workers with credentials as being more productive. These articles revived the 1970s debate on the screening hypothesis (Layard and Psacharopoulos, 1974; Riley, 1979). The approach used by Belman and Heywood (1991) and Hungerford and Solon (1987) is to re-examine Layard and Psacharopoulos' (1974) dismissal of the refutable predictions of the screening hypothesis that wages will rise faster with extra years of education when the extra year also conveys a certificate - the sheepskin effect.

According to Belman and Heywood (1991) and Hungerford and Solon (1987), it is not correct in earnings functions estimations to treat the natural logarithm of the wage rate as a linear function of years of education, with no allowance for discontinuity in diploma years. Estimating earnings functions with discontinuities in years of schooling lends support to the sheepskin prediction and, thus, to the screening hypothesis. Most of the analyses of the sheepskin effect-or the screening hypothesis in general-have been conducted with data from the United States or other advanced countries. Little analysis has used data from less developed countries. Griffin and Cox Edwards (1993) analyze rates of return to education in Brazil using the 1989 annual survey and estimate earnings functions with separate dummy variables for each year of schooling completed. The results indicate a large increase in earnings associated with four years of schooling. This is the largest single year incremental increase in earnings until one reaches 11 years of schooling. This analysis, however, does not support the sheepskin prediction. It only shows that non-linearities in the returns to education exist. Arabsheibani and Manfor 2001 estimate non-linear returns to schooling in Libya but do not argue that they represent sheepskin effects, since some non-diploma years also possess the same earnings advantage. Patrinos (1996) empirically examines non-linearities in the returns to education from another developing country, Guatemala. The results do not support the sheepskin interpretation of the screening hypothesis, but they do suggest non-linearities in the returns to education. Citing the new growth theory literature on threshold externalities (Azariadis and Drazen 1990), and some macroeconomic evidence, it is suggested that there may be individual threshold levels in the returns to education. This is essentially a 
reconfirmation of the original hypothesis which formalized a threshold-type relationship between human capital and economic growth (Bowman and Anderson 1963; Easterlin 1981). Bowman and Anderson (1963) were the first economists to formalize a threshold-type hypothesis which connects economic growth to human capital. Drawing on data from the 1950s, they suggest that a literacy rate of $30-40 \%$ is a precondition for rapid growth. Easterlin (1981) refines this hypothesis. Widespread public education at the basic level may provide a threshold for development. There appears to be a threshold level of minimum average education somewhere between three and four years of schooling in order for education to begin to have an impact at the individual level. To take advantage of potential threshold levels of average education of the labor force, an optimal distribution would appear to be an equitable one, in order to maximize the potential spill-over effects associated with human capital. Widespread public education at the basic level may provide a threshold for development.

There are significant increases associated with particular years of schooling that would represent the attainment of secondary education (Table 3). There are no indications of sheepskin effects at the primary level. There is an indication of sheepskin effects at 17 years of schooling which could represent the attainment of a tertiary degree. However, there are also spikes in earnings at years 7,13 and 15 (Figure 1); these are years not associated with attainment of any certificate. Others have found evidence of thresholds associated with non-certificate years in other countries, including the Unites States (see, for example, Olneck 1977; Hungerford and Solon 1987; Belman and Heywood 1991), where all studies show diploma effects. Evidence from other countries is more mixed, sometimes showing non-linearities but not evidence of sheepskin effects as in the case of Brazil, Guatemala and Libya (Griffin and Cox-Edwards 1993; Patrinos 1996; Arabsheibani and Manfor 2001), and in the case of Pakistan strong evidence of sheepskin effects (Shabbir 1991).

In the case of Argentina it could be that 7 years of schooling may represent a sort of threshold (Azariadis and Drazen 1990), meaning a minimum level of schooling deemed absolutely necessary for effective employment and adequate earnings in the Argentine labor market. It could be considered a sort of "functional literacy." This is similar to the estimate of 8 years by Arabsheibani and Manfor (2001) in the case of Libya. However, Sanmartin (2001) does not find a threshold until 11 years of schooling (achievement of secondary education) in Spain (see also Pons 2006, who also only finds sheepskin effects at complete secondary education for men in Spain), but thereafter the earnings function is linear with no more thresholds or sheepskin effects. 


\section{Macrothink}

Research in Applied Economics

ISSN 1948-5433

2014, Vol. 6, No. 3

Table 3. Estimated Coefficients (and Standard Errors) in Regression of Log Hourly Earnings as Step Function of Years of Schooling

\begin{tabular}{|c|c|c|c|c|}
\hline & & $\begin{array}{c}\text { Estimated } \\
\text { Coefficient }\end{array}$ & $\begin{array}{c}\text { Standard } \\
\text { Error }\end{array}$ & $\begin{array}{c}\text { Implied Step } \\
\text { Sizes }\end{array}$ \\
\hline \multirow[t]{18}{*}{ S } & $=$ & 0.109 & 0.142 & \\
\hline & 2 & 0.243 & 0.118 & 0.134 \\
\hline & 3 & 0.238 & 0.112 & -0.005 \\
\hline & 4 & 0.319 & 0.114 & 0.081 \\
\hline & 5 & 0.250 & 0.117 & -0.070 \\
\hline & 6 & 0.336 & 0.128 & 0.086 \\
\hline & 7 & 0.468 & 0.102 & 0.132 \\
\hline & 8 & 0.546 & 0.108 & 0.078 \\
\hline & 9 & 0.622 & 0.105 & 0.076 \\
\hline & 10 & 0.642 & 0.105 & 0.020 \\
\hline & 11 & 0.743 & 0.109 & 0.101 \\
\hline & 12 & 0.927 & 0.102 & 0.184 \\
\hline & 13 & 1.147 & 0.111 & 0.221 \\
\hline & 14 & 1.134 & 0.109 & -0.013 \\
\hline & 15 & 1.365 & 0.104 & 0.231 \\
\hline & 16 & 1.355 & 0.117 & -0.010 \\
\hline & 17 & 1.782 & 0.104 & 0.428 \\
\hline & 18 & 1.237 & 0.405 & -0.546 \\
\hline \multicolumn{2}{|c|}{ Experience } & 0.041 & 0.002 & \\
\hline \multicolumn{2}{|c|}{ Experience-sq. } & -0.001 & 0.000 & \\
\hline \multicolumn{2}{|c|}{ Constant } & -0.688 & 0.103 & \\
\hline \multicolumn{2}{|c|}{$\mathrm{R}^{2}$} & 0.283 & & \\
\hline \multicolumn{2}{|l|}{$\mathrm{N}$} & 9,309 & & \\
\hline
\end{tabular}

Source: EPH 2002

\subsection{P-test}

We split the sample into public and private employment and compare returns (Table 4). The average return to an additional year of schooling is higher in the private sector. The returns to schooling in the public sector are 10 percent, compared to a higher, 11 percent, in the private sector. In cases where productivity matters, education does continue to have a value after the employee has been under observation for some time (the latter taken into account by the inclusion of the experience variable in the regression). This finding is inconsistent with the strong version of the screening hypothesis. 


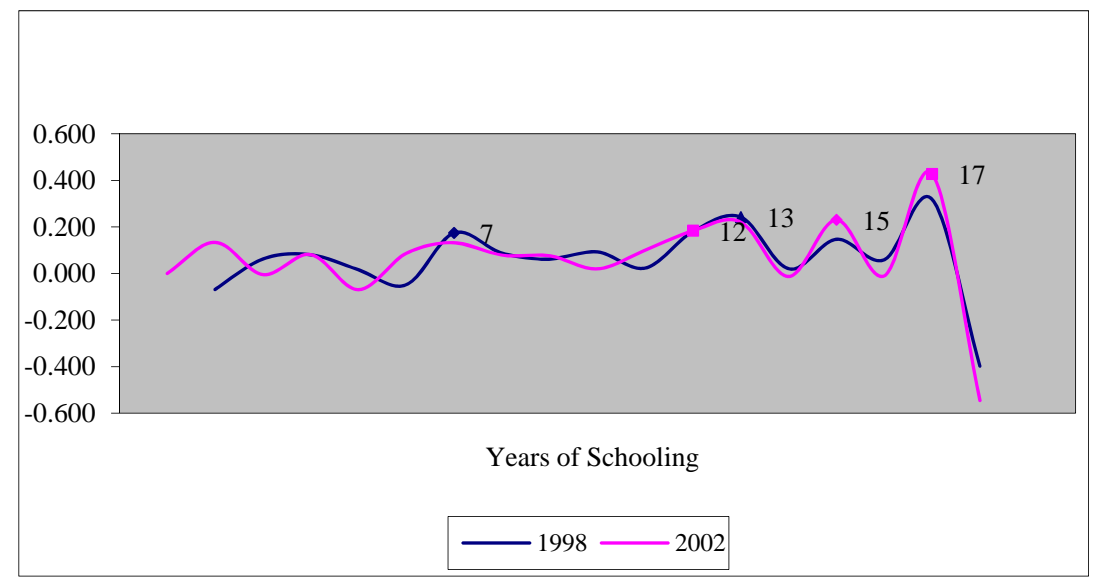

Figure 1. Implied Step Sizes

Source: EPH; see Savanti and Patrinos 2005 for full results

Table 4. Determinants of Earnings by Sector of Employment

\begin{tabular}{llccc}
\hline & \multicolumn{2}{c}{ Public } & \multicolumn{2}{c}{ Private } \\
\hline & Estimated & Standard & Estimated & Standard \\
& Coefficient & Error & Coefficient & Error \\
Years of education & 0.099 & 0.003 & 0.111 & 0.003 \\
Experience & 0.036 & 0.003 & 0.036 & 0.003 \\
Experience-squared & -0.001 & 0.001 & -0.001 & 0.001 \\
Constant & -0.669 & 0.049 & -1.061 & 0.044 \\
$\mathrm{R}^{2}$ & 0.323 & & 0.216 & \\
$\mathrm{~N}$ & 3,085 & & 6,178 & \\
\hline
\end{tabular}

Source: EPH 2002

We also examine returns by level of schooling (Table 5). The results suggest that there may be screening at the primary level in the public sector, but given that relatively few Argentine workers are at this low level of schooling, then it is hard to interpret this finding. Also the returns to schooling are about the same at the secondary level, thus offering no insights on the relative merits of screening. However, at the tertiary level the returns are significantly higher in the private sector, suggesting the absence of screening. The tertiary sector is particularly important given the findings in Fiszbein et al. (2007) and Galiani and Sanguinetti (2003), showing strong demand for skills in Argentina in recent years. Thus, it would appear that the private sector, where productivity is assumed to matter more, values higher skills more. Thus, these findings as well are inconsistent with the strong version of the screening hypothesis. 
Table 5. Determinants of Earnings by Level and by Sector

\begin{tabular}{lcccc}
\hline & \multicolumn{2}{c}{ Public } & \multicolumn{2}{c}{ Private } \\
& Coefficient & Returns & Coefficient & Returns \\
\hline Primary complete & 0.237 & & 0.190 & \\
& $(0.047)$ & 11.9 & $(0.037)$ & 9.5 \\
Secondary incomplete & 0.423 & & 0.351 & \\
& $(0.050)$ & 12.4 & $(0.040)$ & 10.7 \\
Secondary complete & 0.674 & & 0.622 & \\
& $(0.048)$ & 14.6 & $(0.040)$ & 14.4 \\
Tertiary incomplete & 0.837 & & 0.954 & \\
& $(0.055)$ & 6.5 & $(0.047)$ & 13.3 \\
Tertiary complete & 1.185 & & 1.394 & \\
& $(0.049)$ & 10.2 & $(0.045)$ & \\
Experience & 0.034 & & 0.038 & \\
& $(0.003)$ & & $(0.003)$ & \\
Experience-squared & -0.001 & & -0.001 & \\
Constant & $(0.001)$ & & $(0.001)$ & \\
$\mathrm{R}^{2}$ & -0.158 & & -0.443 & \\
$\mathrm{~N}$ & 0.321 & & 0.225 & \\
\hline
\end{tabular}

Source: EPH 2002

Notes: See Table 1

The returns to primary and secondary schooling are higher in the public sector. Tertiary education, whether complete or not, is associated with higher returns in the private sector. This provides little evidence of screening since the private sector seeks to maximize profits and hence recognizes the higher productivity of the more educated relative to the public sector that tends to reward on a pay-scale basis regardless of productivity. In other words, given the higher productivity of those with more education, it could be related to the fact that the private sector pays higher wages for the more productive. Given that the recent increases in the returns to schooling, probably associated with higher demand for more skilled labor, were driven by increases in the returns to schooling at the tertiary level, it appears that the private sector recognizes and rewards appropriately this higher productivity.

The results are in line with what is found in most other developing countries. Still, there is some evidence of sheepskin effects in Brazil (Crespo and Reis 2009), Colombia (Mora 2003), Hong Kong (Heywood and Wei 2004), the Philippines (Schady 2003), and Mexico (Mehta and Villarreal 2008), but not necessarily screening (Skalli 2007). There is more evidence of screening in higher-income, developed countries (Sanmartin 2001; Park 1999; Jaeger and Page 1996; Hungerford and Solon 1987). However, Chevalier et al. (2004), using changes in the compulsory school leaving age in the United Kingdom, find no support for the screening hypothesis. Also, controlling for selection into private and public employment, and using the Hungerford-Solon methodology, Pons and Blanco (2005) find little evidence of sheepskin effects in the private sector and certificate rewards for diplomas in the public sector. Many 
recent analyses find some evidence of screening and the more sophisticated the analysis, that is the deeper it delves into it, the more it shows that while not determinant, there is still some level of screening in most labor markets (see, for example, Bauer and others 2005; Ferrer and Riddell 2002). However, human capital is a productivity-enhancing asset.

\section{Conclusion}

The returns to schooling in Argentina increased over the last decade. This paper examined the extent to which estimated returns to schooling reflect productivity differences in the case of a middle-income country. While our results point to some level of screening, at some levels of schooling, the overall findings are consistent with a human capital interpretation of the relationship between education and earnings.

There do not appear to be significant increases associated with years of schooling that would represent the attainment of a primary or secondary certificate. The only signal that there might be screening occurs at 17 years of schooling which could be argued represents the attainment of a tertiary education degree. However, 15 years of schooling also represents a significant threshold in 2002. The returns to schooling are higher in the private sector. Much of the increase in the returns to schooling overall is due to the increase in the returns to tertiary education. The returns to complete university are higher in the private sector. This provides no evidence of screening since the private sector seeks to maximize profits and recognizes the higher productivity of the more educated. Overall, there is little evidence of screening driving the returns to schooling.

Given the importance of human capital for development, future research should focus on examining the pathways through which education enhances productivity. If the relationship between schooling and earnings is not due to screening, then it must be due to productivity improvements. Finding out how exactly schooling enhances productivity would be useful to designing strategies to improve learning outcomes, especially for the more disadvantaged segments of society.

\section{Acknowledgement}

The views expressed here are those of the authors and should not be attributed to the World Bank Group. 


\section{References}

Arabsheibani, G., \& Rees, H. (1998). On the Weak versus the Strong Version of the Screening Hypothesis. Economics of Education Review, 17, 189-92. http://dx.doi.org/10.1016/S0272-7757(97)00020-4

Arabsheibani, G.R., \& Manfor, L. (2001). Non-Linearities in Returns to Education in Libya. Education Economics, 9, 139-144. http://dx.doi.org/10.1080/09645290110056976

Arrow, K.J. (1973). Higher Education as a Filter. Journal of Public Economics, 3, 193-216. http://dx.doi.org/10.1016/0047-2727(73)90013-3

Azariades, C., \& Drazen, A. (1990). Threshold Externalities in Economic Development. Quarterly Journal of Economics, 105, 501-526. http://dx.doi.org/10.2307/2937797

Bauer, T.K., Dross, P.J., \& Haisken-DeNew, J.P. (2005). Sheepskin Effects in Japan. International Journal of Manpower, 320-335. http://dx.doi.org/10.1108/01437720510609528

Becker, G.S. (1964). Human Capital: A Theoretical and Empirical Analysis with Special Reference to Education. New York: Columbia University Press.

Bedard, K. (2001). Human Capital versus Signaling Models: University Access and High School Dropouts. Journal of Political Economy, 109, 749-775. http://www.jstor.org/stable/10.1086/322089

Belman, D., \& Heywood, J. (1991). Sheepskin Effects in the Returns to Education. Review of Economics and Statistics, 73, 720-724. http://www.jstor.org/stable/2109413

Bitzan, J.D. (2009). Do sheepskin effects help explain racial earnings differences? Economics of Education Review, 28, 759-766. http://dx.doi.org/10.1016/j.econedurev.2008.10.003

Bowman, M.J., \& Anderson, C.A. (1963). Concerning the role of education in development. In C. Greets, ed., Old Societies and New States: The Quest for Modernity in Asia and Africa. London: Collier-Macmillan, 247-79.

Brown, S., \& Sessions, J.G. (1999). Education and employment status: a test of the strong screening hypothesis in Italy. Economics of Education Review, 18, 397-404. http://dx.doi.org/10.1016/S0272-7757(99)00002-3

Brown, S., \& Sessions, J.G. (2006). Evidence on the relationship between firm-based screening and the returns to education. Economics of Education Review, 25, 498-509. http://dx.doi.org/10.1016/j.econedurev.2005.05.007

Brown, S., \& Sessions, J.G. (2004). Signalling and Screening. In G. Johnes and J. Johnes, eds., International Handbook on the Economics of Education. Cheltenham: Edward Elgar.

Chevalier, A. et al. (2004). Does Education Raise Productivity, or Just Reflect It? Economic Journal, 114, F499-F517. http://dx.doi.org/10.1111/j.1468-0297.2004.00256.x 
Cohn, E. et al. (1987). Further Evidence on the Screening Hypothesis. Economics Letters, 25, 289-94. http://dx.doi.org/10.1016/0165-1765(87)90230-8

Crespo, A., \& Reis, M.C. (2009). Sheepskin effects and the relationship between earnings and education: analyzing their evolution over time in Brazil. Revista Brasileira de Economia, 63, 209-2312. http://dx.doi.org/10.1590/S0034-71402009000300002

Ferrer, A.M., \& Riddell, W.C. (2002). The Role of Credentials in the Canadian Labour Market. Canadian Journal of Economics, 35, 879-905. http://dx.doi.org/10.1111/0008-4085.00158

Fiszbein, A. et al. (2007). Estimating the Returns to Education in Argentina Using Quantile Regression Analysis: 1992-2002. Económica, 53, 53-72. http://economica.econo.unlp.edu.ar/documentos/20081127033457PM_Economica_555. pdf

Galiani, S., \& Sanguinetti, P. (2003). The Impact of Trade Liberalization on Wage Inequality: Evidence from Argentina. Journal of Development Economics, 72, 497-513. http://dx.doi.org/10.1016/S0304-3878(03)00117-2

Gibson, J. (2000). Sheepskin Effects and the Returns to Education in New Zealand: Do They Differ by Ethnic Groups? New Zealand Economic Papers, 34, 201-220. http://dx.doi.org/10.1080/00779950009544323

Griffin, P., \& Cox-Edwards, A. (1993). Rates of Return to Education in Brazil: Do Labor Market Conditions Matter? Economics of Education Review, 12, 245-255. http://dx.doi.org/10.1016/0272-7757(93)90007-4

Heywood, J.S., \& Wei, X. (2004). Education and Signaling: Evidence from a Highly Competitive Labor Market. Education Economics, 12, 1-16. http://dx.doi.org/10.1080/0964529042000193925

Hungerford, T., \& Solon, G. (1987). Sheepskin Effects in the Returns to Education. Review of Economics and Statistics, 69, 175-177. http://www.jstor.org/stable/1937919

Jaeger, D.A., \& Page, M.E. (1996). Degrees Matter: New Evidence on Sheepskin Effects in the Returns to Education. Review of Economics and Statistics, 78, 733-740. http://www.jstor.org/stable/2109960

Lambropoulos, H. (1992). Further Evidence on the Weak and Strong Versions of the Screening Hypothesis in Greece. Economics of Education Review, 11, 61-65. http://dx.doi.org/10.1016/0272-7757(92)90022-U

Layard R., \& Psacharopoulos, G. (1974). The Screening Hypothesis and the Returns to

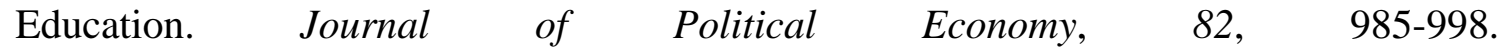
http://www.jstor.org/stable/1829179

Mehta, A., \& Villarreal, H. (2008). Why do diplomas pay? An expanded Mincerian framework applied to Mexico. Applied Economics, 40, 3127-3144. 
http://dx.doi.org/10.1080/00036840600994120

Mora, J.J. (2003). Sheepskin Effects and Screening in Colombia. Colombian Economic Journal, 1, 96-108.

Olneck, M. (1977). The Effect of Education. In C. Jencks, ed., Who Gets Ahead? The Determinants of Educational Success in America. New York: Basic Books.

Park, J.H. (1999). Estimation of Sheepskin Effects Using the Old and the New Measures of Educational Attainment in the Current Population Survey. Economics Letters, 62, 237-240. http://dx.doi.org/10.1016/S0165-1765(98)00226-2

Patrinos, H. (1996). Non-linearities in the Returns to Education. Applied Economics Letters, 3, 171-173. http://dx.doi.org/10.1080/135048596356609

Pons, E. (2006). Diploma Effects by Gender in the Spanish Labour Market. Labour, 20, 139-157. http://dx.doi.org/10.1111/j.1467-9914.2006.00292.x

Pons, E., \& Blanco, J.M. (2005). Sheepskin Effects in the Spanish Labour Market: A Public-Private Sector Analysis. Education Economics, 13, 331-347. http://dx.doi.org/10.1080/09645290500073852

Psacharopoulos, G. (1979). On the weak versus the strong version of the screening hypothesis. Economics Letters, 4, 181-185. http://dx.doi.org/10.1016/0165-1765(79)90232-5

Riley, J.G. (1979). Testing the educational screening hypothesis. Journal of Political Economy, 87, S227-52. http://www.jstor.org/stable/1817230

Sanmartin, M. (2001). Linearity of the Return to Education and Self Selection. Applied Economics, 33, 133-142. http://dx.doi.org/10.1080/00036840121772

Savanti, M.P., \& Patrinos, H. A. (2005). Rising returns to schooling in Argentina, 1992-2002: productivity or credentialism? World Bank Policy Research Working Paper, (3714).

Schady, N.R. (2003). Convexity and Sheepskin Effects in the Human Capital Earnings Function: Recent Evidence for Filipino Men. Oxford Bulletin of Economics and Statistics, 65, 171-196. http://dx.doi.org/10.1111/1468-0084.00042

Schultz, T.W. (1961). Investment in Human Capital. American Economic Review, 1, 1-17. http://www.jstor.org/stable/1818907

Shabbir, T. (1991). Sheepskin Effects in the Return to Education in a Developing Country. Pakistan Development Review, 30, 1-19. http://www.jstor.org/stable/41259446

Skalli, A. (2007). Are successive investments in education equally worthwhile? Endogenous schooling decisions and non-linearities in the earnings-schooling relationship. Economics of Education Review, 26, 215-231. http://dx.doi.org/10.1016/j.econedurev.2005.07.004

Spence, M. (1973). Job Market Signaling. Quarterly Journal of Economics, 87, 355-374. http://www.jstor.org/stable/1882010 


\section{Macrothink}

Research in Applied Economics

ISSN 1948-5433

2014, Vol. 6, No. 3

Stiglitz, J.E. (1975). The Theory of Screening, Education, and the Distribution of Income. American Economic Review, 65, 283-300. http://www.jstor.org/stable/1804834

\section{Copyright Disclaimer}

Copyright for this article is retained by the author(s), with first publication rights granted to the journal.

This is an open-access article distributed under the terms and conditions of the Creative Commons Attribution license (http://creativecommons.org/licenses/by/3.0/). 